\title{
Analysis of the Effect of Militancy Activities on Students Enrollment in Niger Delta: Implications for Adult and Vocational Education
}

\author{
Gloria Olori ${ }^{1}$, Dorida Oyigbo ${ }^{2}$, Iheanyichukwu Ozurumba ${ }^{2}$, Christian Olori ${ }^{2}$, Judith Ugwuoke ${ }^{2}$, Chinyere \\ $\mathrm{Anigbogu}^{2} \&$ Beatrice Onah $^{2}$ \\ ${ }^{1}$ Department of Business Education, Faculty of Vocational and Technical Education, University of Nigeria, Nsukka, \\ Nigeria \\ ${ }^{2}$ Department of Adult Education and Extra Mural Studies, Faculty of Education, University of Nigeria, Nsukka, \\ Nigeria \\ Correspondence: Christian Olori, Department of Adult Education and Extra Mural Studies, Faculty of Education, \\ University of Nigeria, Nsukka, Nigeria.
}

Received: November 5, 2020

Accepted: August 5, 2021

Online Published: August 9, 2021

doi:10.5430/ijhe.v11n1p108

URL: https://doi.org/10.5430/ijhe.v11n1p108

\begin{abstract}
With the continuous decline on students' enrollment in adult and vocational education in Niger Delta region, this study sets to analyse the effect of militancy activities and its impact on educational development. It adopted the ex post facto type of the descriptive research. The sample of 347 students was used to respond to the data collecting instrument. Based on the analysis, the existence of poor synergy between teacher and students and scanty population were notable as the effects of the insurgency. Further analysis showed that students' poor academic performance, high illiteracy level and increase in youth restiveness were found to have highly impacted on the educational development.
\end{abstract}

Keywords: analysis, militancy activities, students, enrollment, Niger Delta

\section{Introduction}

\subsection{Problem of the Study}

The activities of the insurgent groups in the destruction of lives and property have attracted concerns by scholars especially in the areas of investigating the rote causes of their actions and consequences on educational development. These destructive acts may not have been unattributed to the deplorable condition of the people whose means of livelihood have been destroyed through oil exploration and exploitation by multinational oil companies. The region suffered from administrative neglect, crumbling social deprivation, abject poverty, filth and squalor and endemic conflict (United Nations Development Programme (UNDP), 2006).

Militancy is a violent mode of action of aggrieved people, group or activists geared towards political, social, economic or religious emancipation (Arowosegbe, 2009). These actions are purported at defending a cause which are but not limited to deprivation, persistent injustice, inequality, marginalisation, illiteracy, diseases, malnutrition, joblessness and poverty (Ibaba as cited by Uriah, Egbezor \& Ololube, 2014; Egbe, 2014; Odalonu \& Obani, 2018). Some of the aggrieved groups are Niger Delta Vigilante Force (NDVF), Movement of the Niger Delta People (MONDP), Movement for the Emancipation of the Niger Delta (MEND), Niger Delta People Salvation Front (NDPSK), Niger Delta Avengers (NDA), Joint Revolutionary Council (JRC) and the Movement of the Survival of the Ijaw Ethnic Nationality (MOSEIN). Furthermore, the activities of these groups comprise armed robbery, assassination, rapping, fire outbreak, kidnapping, violent destruction of property, vandalisation of pipelines and students' unrest among others (Okafor, 2008).

Consequently, students' unrest is precipitated by militancy activities. This unrest is a state of turbulence and confusion in learning conditions of students in adult and vocational education as relate to the study. Adult education comprises all forms of education and learning that aim to ensure that all adults participate in their societies and the world of work (UNESCO \& UIL, 2016). This education denotes the entire body of learning processes formal, non formal and informal whereby those regarded as adults by the society in which they live, develop and enrich their capabilities for living and working, both in their own interests and those of their communities, organisations and societies. Vocational education on the other hand, involves the practice of highly versatile skill based careers 
teaching to students in various levels of education. It is an education that prepares one for gainful living through the acquisition of practical skills irrespective of the level of training, for self reliance. Vocational education includes every form of education that aims at the acquirement of qualifications related to a certain profession, art, employment or that which provides the necessary training and the appropriate skills as well as technical knowledge to make students exercise activities independently of their age and their training level even if the training programme contains also elements of general education (Kotsikis, 2007).

It could therefore be deduced that the sole objective of these forms of education is the improvement in the standard of living of the learners for active participation in national development. Suffice it to say that adult and vocational education are directed at enhancing self employment and economic productivity while reducing poverty among the learners. Thus, the effective acquisition of skills and competencies by these recipients is predicated on learning environment devoid of threats and distractions. Such environments encourage students' motivation and healthy participation in learning, with adequate provision of facilities, good academic environment, protective and safe (Amaele, 2013). However, preliminary investigations in selected learning environments in the region showed high illiteracy, lack of interest to learning activities by students and resistance to change, unruly students behaviour among others. This observation is in tandem with the view that there is a significant relationship between learning environment and students' academic performance (Ibiloye, 2003).

In spite of the direct relationship, empirical evidences on effect of militancy activities on students' enrollment in adult and vocational education as well as its consequences on educational development have not been given sufficient attention by scholars especially in Niger Delta region of Nigeria, hence, the continuous loss of interest by students to learning and high level of illiteracy. Furthermore, the insufficient attention by scholars has invariably limited the knowledge spread of the effect of militancy activities on educational development especially in adult and vocational education. To this end, the present study tries to contribute to literature on the effect of militancy activities on students' enrollment in adult and vocational education and its consequences on educational development in Niger Delta region.

\subsection{Theoretical Background of the Study}

The study was anchored on skill acquisition theory propounded by Hubert and Dreyfus in 1980. The theory maintains that the acquisition of skills in a formal system is a gradual process that is embodied in different ways. The theorists further explained the five stages an individual goes through; as novice, advanced beginner, competence, proficiency and expertise. These stages form the idea behind 'knowing that' and 'knowing how' associated with skill development theories of Hubert and Dreyfus. 'Knowing that' and 'knowing how' become a concept acquired through a formal system of skill acquisition in adult and vocational education. Although, this skill acquisition process of 'knowing that' and 'knowing how' is disputed by some scholars in terms of phases in learning, the theorists stipulated that the two concepts are gradual process involved for an individual to go through in order to reach the stage of expertise. Skill acquisition process shows that an individual goes through at least five stages of different knowledge of a specific task and ways of decision making as he improves his skill. This implies that for any meaningful improvement to take place in the quality of life of an individual, the acquisition of various competencies is required by the students to be able to fight poverty. This theory is relevant to the present study since the rise in poverty level among the students amidst other reasons is attributed to deprivation from free threat learning environment to acquire appropriate skills for self reliance.

\subsection{Review of Related Empirical Studies}

Various studies have been conducted on insurgency and its effects on educational development. Uriah, Egbezor and Ololube (2014) revealed that natural resources, peer group, mass media, unemployment, poverty, bad government and corruption affected educational development of Rivers State. Ogbugo-Ololube (2016) revealed that militancy variables such as hostage taking/ abduction, poverty and weapon possession by students significantly influenced educational development. Kola and Akanbi (2013) revealed that lack of qualified science teachers, lack of instructional materials, low students' interest and lack of motivation among others cause low enrolment in science. Pepple and Ogologo (2017) showed that students from crisis unaffected schools have greater basic science achievement than their peers from affected areas. Oladunjoye and Omemu (2013) found that there was no significant difference is school attendance among male and female pupils and students in Northern Nigeria. Furthermore, significant difference was found in school attendance among primary, secondary and tertiary institutions in areas prone to Boko Haram attacks. Mohammed, Ibrahim and Suleiman (2017) found that educational output was affected by school enrollment, school attendance and school infrastructure by $71 \%, 84 \%$ and $82 \%$ as a result of any $1 \%$ increase in Boko Haram. Furthermore, extreme religious beliefs, unemployment, and illiteracy contributed to the 
occurrence of Boko Haram. Mohammed and Ibrahim (2019) revealed that the effect of Boko Haram insurgency was high on students' enrolment and attendance. More so, students' performance was affected psychologically following the abduction of students, killings, as well as destruction of properties in schools.

Consequently, activities of militancy have direct relationship on educational development. None of the reviewed studies studied militancy activities, its effects on adult and vocational education and consequences on educational development in Niger Delta region. This gap in literature necessitated the present study. In a digital world, it is believed that the provision of necessary technological gadgets in learning environment especially adult and vocational education are essential for safety and quality learning. Other countries especially the developed, have introduced these gadgets for effective learning even in adult and vocational education, these however are lacking in developing countries like Nigeria and most especially in Niger Delta region. Hence, the study determined the effects of militancy activities on students' enrollment in adult and vocational education and its consequences on educational development in Niger Delta region, Nigeria.

\section{Methods}

\subsection{Design of the Study}

The descriptive survey using ex post facto type of research was used for the study. This type of research involves measuring the outcome of an already existing militancy activities on adult and vocational education. The design has been used by Pepple and Ogologo (2017) for similar study.

\subsection{Ethical Considerations}

To ensure students participation in the study, the rationale of the study was explained to the participants. Furthermore, participants were asked to voluntarily sign a consent form and were assured of the confidentiality of the information released for the sole purpose of the study.

\subsection{Participants}

A sample of 347 students in adult and vocational education was used for the study. The multi stage sampling procedure was used for the selection of the respondents using purposive and simple random sampling techniques.

\subsection{Instrument}

The researchers' structured instrument titled, Questionnaire on Effects of Militancy Activities on Students' Enrollment (QEMASE) was used for data collection. The QEMASE had two clusters addressing the two objectives of the study. Cluster A was on the effects of militancy activities on students 'enrollment in adult and vocational education with 10 items on a four point rating scale of strongly agree (4-points), agree (3-points), disagree (2-points) and strongly disagree (1-point). The cluster B elicited information on consequences of militancy activities on educational development with 12 items. The items were rated as very high impact (4-points), high impact (3-points), moderate impact (2-points) and low impact (1-point). The questionnaire was further subjected to face validation by three experts, each from Adult Education Department, Business Education Department and Measurement and Evaluation Unit of the Department of Science Education all from the University of Nigeria, Nsukka, Enugu State. The reliability coefficient values of .83 and .89 were obtained for clusters A and B using the Cronbach Alpha Statistical tool.

\subsection{Procedure for Administration of Instrument}

The researchers administered the questionnaire to the students having sought the permission of the school authorities. This was to ensure that adequate attention was given by the students in responding to the statements in the questionnaire. More so, it was believed that informing the school authorities, there could be adjustment in their activities to reduce distractions as to obtain correctness of information from respondents. Thus, helping in the achievement of the objective for the study.

\subsection{Data Analysis}

Data obtained from the respondents were subjected to descriptive statistics of mean and standard deviation. The computation was done using the Statistical Package for Social Science software version 23. For cluster A, decision was based on the criterion mean of 2.50. This means that mean score with 2.50 and above was regarded as agree, while below 2.50 was disagree. For cluster B, the real limit of numbers was used for decision making. This was stated as follows: very high extent $(3.50-4.00)$, high extent $(2.50-3.49)$, moderate extent $(1.50-2.49)$ and low extent $(1.00-1.49)$. 


\section{Results}

Out of the 347 copies of the questionnaire administered, a total of 342 representing $98.6 \%$ was valid for the study as they were correctly filled, while five representing $1.4 \%$ were wrongly filled as such discarded from analysis.

Table 1. Mean responses of respondents on effects of militancy activities on students' enrollment $(n=342)$

\begin{tabular}{llrll}
\hline S/N & Item statement & $\overline{\boldsymbol{x}}$ & SD & Remarks \\
\hline 1 & Withdrawal from school & 2.81 & .70 & Agree \\
2 & Scanty population of students & 2.90 & .70 & Agree \\
3 & Loss of fantasy in school extra curricula activities & 2.57 & .69 & Agree \\
4 & Poor enrollment in external examination & 2.59 & .83 & Agree \\
5 & Fear of being kidnapped & 2.71 & .66 & Agree \\
6 & Poor teacher- students relationship & 3.16 & .63 & Agree \\
7 & Poor enrollment in internal examination & 2.56 & .69 & Agree \\
8 & Truncated scheme of teaching activities & 2.47 & .71 & Disagree \\
9 & Students loss of interest in self learning & 2.77 & .71 & Agree \\
10 & Poor students- students relationship & 2.50 & .72 & Agree \\
& Cluster mean & $\mathbf{2 . 7 0}$ & $\mathbf{. 7 0}$ & Agree \\
\hline
\end{tabular}

Note: $\bar{x}=$ Mean, $S D=$ Standard deviation

Table 1 revealed that nine out of the I0 items had agree as their remark with mean scores ranging from $2.50-3.16$, while the standard deviations ranged from .63 to .83 , indicating the nearness in the spread of the mean scores. Notably among the scores were: poor teacher- students relationship (3.16; $\mathrm{SD}=.63$ ), scanty population of students (2.90; $\mathrm{SD}=.70)$, withdrawal from school (2.81; $\mathrm{SD}=.70)$, and students' loss of interest in self learning (2.77; $\mathrm{SD}=.71)$. The Table further had fear of being kidnapped as (2.71; $\mathrm{SD}=.66)$, poor enrollment in external examination (2.59; $\mathrm{SD}=.83)$, poor enrollment in internal examination $(2.56 ; \mathrm{SD}=.69)$ and loss of students- students relationship (2.50; $\mathrm{SD}=.72)$, while truncated scheme of teaching activities had a mean score of disagree $(2.47 ; \mathrm{SD}=.71)$. From the Table, it was deduced that poor teacher- students relationship, fewer students' population and withdrawal from school were mostly associated with the effects of militancy activities on students' enrollment in adult and vocational education.

Table 2. Mean responses of respondents on consequences of militancy activities on educational development ( $\mathrm{n}$ $=342$ )

\begin{tabular}{llccl}
\hline S/N & Item statement & $\overline{\boldsymbol{x}}$ & SD & Remarks \\
\hline 1 & Poor students' academic performance & 2.70 & .77 & High Extent \\
2 & High level of illiteracy & 2.70 & .77 & High Extent \\
3 & Poor skilled students' turnout & 2.53 & .74 & High Extent \\
4 & Increase in youth restiveness & 2.70 & .73 & High Extent \\
5 & Poor students' academic achievement & 2.62 & .67 & High Extent \\
6 & Loss of confidence in performing a given task & 2.46 & .81 & Low Extent \\
7 & Poor interest to learning by prospective students & 2.52 & .71 & High Extent \\
8 & Poor motivation to learning & 2.43 & .73 & Low Extent \\
9 & Students resistance to change & 2.52 & .71 & High Extent \\
10 & High level of poverty & 2.54 & .78 & High Extent \\
11 & High emotional trauma by students & 2.54 & .78 & High Extent \\
12 & Poor quality of education & 2.50 & .71 & High Extent \\
& Cluster mean & $\mathbf{2 . 5 4}$ & $\mathbf{. 7 4}$ & High Extent
\end{tabular}

Note: $\bar{x}=$ mean,$S D=$ Standard Deviation 
Table 2 indicated that eight items had mean scores classified within the limit $(2.50-3.49)$ as high extent with corresponding standard deviations ranging from .67 to .78 . Prominent among these scores as revealed on the Table were: poor students' academic performance $(2.70 ; \mathrm{SD}=.77)$, high level of illiteracy $(2.70 ; \mathrm{SD}=.77)$, increase in youth restiveness $(2.70 ; \mathrm{SD}=.73)$, and poor students' academic achievement $(2.62 ; \mathrm{SD}=.67)$. Others in their ascending orders were: high level of poverty $(2.54 ; \mathrm{SD}=.78)$, high emotional trauma by students $(2.54 ; \mathrm{SD}=.78)$, poor skilled students turnout $(2.53 ; \mathrm{SD}=.74)$, poor interest to learning by prospective students $(2.52 ; \mathrm{SD}=.71)$, students resistance to change $(2.52 ; \mathrm{SD}=.71)$ and poor quality of education $(2.50 ; \mathrm{SD}=.71)$. The Table further had the mean scores of low on loss of confidence in performing a given task $(2.46 ; \mathrm{SD}=.81)$ and poor motivation to learning $(2.43 ; \mathrm{SD}=.73)$. From the Table, it was deduced that students' poor academic performance, high level of illiteracy and increase in youth restiveness were mostly associated with the consequences of militancy activities on educational development.

\section{Discussions}

The effects of militancy activities on students' enrollment in adult and vocational education were enormous. From the result, poor teacher - students' relationship was prominent. The existence of poor synergy between the teacher and students in adult and vocational education owing to militancy activities was manifested in diverse ways. Some of which were poor students' enrollment and attendance. This invariably resulted to scanty students population in insurgent proned school environment in the region, thus, corroborating with the findings of Mohammed, Ibrahim and Suleiman (2017), and Mohammed and Ibrahim (2019). Other effects included loss of interest in self learning and fear of being kidnapped. The psychological trauma faced by these students may have resulted to their low interest in learning activities, poor enrollment in both internal and external examinations as further attested in findings (Kola \& Akanbi, 2013; Oladunjoye \& Omemu, 2013).

The findings of the study further revealed diverse consequences of militancy activities on educational development. These consequences ranged from disempowerment of individuals to poor quality of education. Disempowerment as revealed in the study was manifested in the following: students' poor academic performance, high illiteracy level, poor academic achievement and high level of poverty. The inability of an individual to effectively participate, function and utilise opportunities for improvement in standard of living and that of the society reveals deficiency in educational development. These scenarios were further supported by the findings of Mohammed, Ibrahim and Suleiman (2017); Pepple and Ogologo (2017); and Ogbugo-Ololube (2016). Other consequences included increase in youth restiveness which is attributable to unemployment as supported in the findings of Uriah, Egbezor and Ololube (2014), students' emotional trauma and resistance to change especially in terms of adaptability to technological innovations and creativity. Looking at these consequences of militancy activities on educational development, it becomes quite glaring that measures be taken to ameliorate its effects in adult and vocational education. The action is timely considering the fact that these forms of education are geared at improvement in the quality of life of learners for their active participation in national development in the modern world. Consequently, in contributing to the existing body of knowledge, the researchers, in this study tried to uncover the effects of militancy activities on students' enrollment in adult and vocational education in Niger Delta region of Nigeria.

\section{Conclusion}

The insurgent activities of militancy have posed several challenges on learning in adult and vocational education and its consequences have in no small measure inhibited educational development in Niger Delta region. Based on the foregoing, the researchers therefore recommended that:

1. Security gadgets be provided by the government through the ministry of education and multinational companies operating in the region for effective learning in adult and vocational education.

2. Safety tips be taught to students of adult and vocational education by safety and security personnel on how to avoid sudden threat occurrence in the learning environment.

\section{References}

Amaele, S. (2013). Quality education, the best pro-active measure to examination malpractice in our formal institutes of learning. Journal of Economics and Sustainable Development, 4(12), 66-70.

Arowosegbe, J. O. (2009). Violence and national development in Nigeria: The political economy of youth restiveness in the Niger Delta. Review of African Political Economy, 36(122), 575-594. https://doi.org/10.1080/03056240903346178

Egbe, E. J. (2014). Rural and community development in Nigeria: An assessment. Arabian Journal of Business and 
Management Review (Nigerian Chapter), 2(2), 17-29. https://doi.org/10.12816/0003723

Hubert, A., \& Dreyfus, S. (1980). Theory of skill acquisition. London: Taylor and Francis

Ibitoye, S. A. (2003). Relationship among school size, resource utilisation and school effectiveness in Ilorin Local Government Area, Kwara State. Unpublished M.Ed thesis, University of Ilorin.

Kola, A. J., \& Akanbi, A. G. (2013). Perceived causes of students low enrolment in science in secondary schools, Nigeria. International Journal of Secondary Education, 1(5), 18-22. https://doi.org/10.11648/j.ijsedu.20130105.11

Kotsikis, V. (2007). Educational Administration and Policy. Athens: Ellin.

Mohammed, B., \& Ibrahim, B. I. (2019). Impact of Boko Haram Insurgency on Students performance in Adamawa State, Nigeria. Dutse Journal of Economics and Development Studies (DUJEDS), 7(2), 83-91.

Mohammed, B., Ibrahim, B. I., \& Suleiman, G. P. (2017). Analysis of the impact of Boko Haram Insurgency on education in Adamawa State, Nigeria. International Journal of Academic Research and Reflection, 5(6), 45-56.

Odalonu, B. H., \& Obani, E. F. (2018). The impact of militancy, insecurity and forced displacement on Nigerian economy. International Journal of Research and Innovation in Social Science, II(X), 1-8.

Ogbugo-Olulube, R. (2016). The influence of militancy variables on educational development of secondary schools in Rivers State, Nigeria. International Journal of Scientific Research in Education, 9(4), 238-247.

Okafor, C. (2008), Empowering women: An alternative mechanism in resolving the Niger Delta crisis. Nigerian State, Oil Industry and the Niger Delta: Conference Proceedings. Port Harcourt: Harey Publication Company.

Oladunjoye, P., \& Omemu, F. (2013). Effect of Boko Haram on School Attendance in Northern Nigeria. British Journal of Education, 1(2), 1-9.

Pepple, T. F., \& Ogologo, G. A. (2017). The effects of the Niger Delta Crisis on educational resources, attitude to schooling, and academic achievement of basic science students in Rivers State, Nigeria. Journal of the International Society for Teacher Education, 21(1), 67-76.

United Nations Development Programme (UNDP) (2006). Niger Delta human development report. Abuja: UN House.

United Nations Educational, Scientific and Cultural Organisation (UNESCO) \& UNESCO Institute for Lifelong Learning (UIL) (2016). Recommendation on Adult Learning and Education. France: UNESCO and UIL.

Uriah, O. A., Egbezor, D. E., \& Olulube, N. P. (2014). The challenges of youth restiveness and educational development in Rivers State. International Journal of Scientific Research in Education, 7(2), 105-130.

\section{Copyrights}

Copyright for this article is retained by the author(s), with first publication rights granted to the journal.

This is an open-access article distributed under the terms and conditions of the Creative Commons Attribution license (http://creativecommons.org/licenses/by/4.0/). 